\author{
A.S. Berdyshev ${ }^{1,2}$, Zh.A. Abdiramanov ${ }^{1,2 *}$, D.N. Blieva ${ }^{2}$, \\ N.S. Akhtaeva ${ }^{2}$ \\ ${ }^{1}$ Abay Kazakh National Pedagogical University,Kazakhstan, Almaty \\ ${ }^{2}$ Institute of Information and Computational Technologies, Kazakhstan, Almaty \\ *e-mail: a.janars@gmail.com
}

\title{
A BRIEF OVERVIEW OF MODERN RESEARCH OF THE PROCESSES DYNAMICS IN UNSTEADY WATER FLOWS USING THE SHALLOW WATER EQUATION
}

In hydrodynamics (hydraulics), there are numerous approaches to solving the problem of water flow dynamics control in river beds and channels, while the results of each methods differ, and estimates of their reliability do not always exist. The shallow water equation (or Saint-Venant's equations in one-dimensional form) is often used by hydraulic engineers in their practice. Its apparent simplicity and ability to describe well enough the behavior of rivers and flows make it a useful tool for many applications, such as the regulation of navigable rivers and irrigation networks in agriculture. The main direction of research in the field of numeric problems described by Saint-Venant equations is the development of numerical methods of computation implemented on super-powerful computers. Development of numerical models of surface water dynamics in the shallow water approximation is actively advancing during the recent years.

The article is devoted to a review of mathematical studies of the dynamics of processes in unsteady water flows using differential equations, as well as an assessment of these approaches from the point of view of the model's reflection of real processes.

The work is aimed at analyzing different approaches to modeling the dynamics of processes in nonstationary water flows. The objectives of the study include the analysis of scientific publications with different approaches to modeling the shallow water equation, taking into account factors, parameters, and modeling methods.

Key words: Saint-Venant equations, dynamics of unsteady river currents, numerical methods, a system of hyperbolic differential equations, high-performance computing.

\footnotetext{
А.С. Бердышев ${ }^{1,2}$, Ж.А. Абдираманов ${ }^{1,2 *}$, Д.Н. Блиева ${ }^{2}$, Н.С. Ахтаева ${ }^{2}$

${ }^{1}$ Абай атындағы Қазақ ұлттық педагогикалық университеті, Қазақстан, Алматы қ.

${ }^{2}$ Ақпараттық жөне есептеуіш технологиялар институты, Қазақстан, Алматы қ.

*e-mail: a.janars@gmail.com
}

Таяз су теңдеуін қолдана отырып, тұрақсыз су ағындарындағы процестердің динамикасы туралы қазіргі заманғы зерттеулерге қысқаша шолу

Гидродинамикада (гидравликада) өзен арналары мен арналардағы су ағынының динамикасын басқару мәселесін шешудің көптеген тәсілдері бар, әр әдістің нәтижелері әр түрлі және олардың сенімділігін бағалау әрдайым бола бермейді. Таяз су теңдеуін (немесе Сен-Венан теңдеулерін бір өлшемді түрде) гидротехниктер өз тәжірибесінде жиі қолданады. Оның айқын қарапайымдылығы мен өзендер мен ағындардың мінез-құлқын жақсы сипаттау қабілеті оны көптеген қосымшалар үшін пайдалы құралға айналдырады, мысалы, өзендерді тасымалдау және ауыл шаруашылығындағы суару желілерін реттеу. Сен-Венан теңдеулерімен сипатталған Сандық есептер саласындағы зерттеулердің негізгі бағыты ауыр компьютерлерде жүзеге асырылатын сандық есептеу әдістерін жасау болып табылады. Соңғы жылдары таяз суға жақындағанда жер үсті суларының динамикасының сандық модельдерін жасау белсенді түрде дамып келеді. 
Мақалада дифференциалдық теңдеулерді қолдана отырып, стационарлық емес су ағындарындағы процестердің динамикасын математикалық зерттеулерге шолу, сонымен қатар нақты процестер моделінде шағылысу тұрғысынан осы тәсілдерді бағалау қарастырылған. Жұмыс стационарлық емес су ағындарындағы процестердің динамикасын модельдеудің әртүрлі тәсілдерін талдауға бағытталған. Зерттеу міндеттеріне факторларды, параметрлерді және модельдеу әдістерін ескере отырып, таяз су теңдеуін модельдеудің әртүрлі тәсілдері бар ғылыми жарияланымдарды талдау кіреді.

Түйін сөздер: Сен-Венан теңдеулері, тұрақты емес өзен ағыстарының динамикасы, сандық әдістер, гиперболалық дифференциалдық теңдеулер жүйесі, жоғары өнімді есептеулер

\author{
А.С. Бердышев ${ }^{1,2}$, Ж.А. Абдираманов ${ }^{1,2 *}$, Д.Н. Блиева ${ }^{2}$, Н.С. Ахтаева ${ }^{2}$ \\ ${ }^{1}$ Казахский Национальный педагогический университет им. Абая, Казахстан, г. Алматы \\ ${ }^{2}$ Институт информационных и вычислительных технологий, \\ Казахстан, г. Алматы \\ *e-mail: a.janars@gmail.com \\ Краткий обзор современных исследований динамики процессов в неустановившихся \\ течениях воды с помощью уравнения мелкой воды
}

В гидродинамике (гидравлике) сосуществуют многочисленные подходы к решению проблемы управления динамикой водных потоков в руслах рек и каналов, причем результаты по различным методам различаются, а оценки их достоверности не всегда существуют. Уравнение мелкой воды (или уравнения Сен-Венана в одномерной форме) часто используется инженер-гидротехниками в своей практике. Их кажущаяся простота и их способность достаточно хорошо описывать поведение рек и водотоков делают их полезным инструментом для многих приложений, таких как, например, регулирование судоходных рек и ирригационных сетей в сельском хозяйстве. Основным направлением исследований в области расчета задач, описанных уравнениями Сен-Венана, является разработка численных методов расчета, реализуемых с помощью использования сверхмощных вычислительных компьютеров. Разработки численных моделей динамики поверхностных вод в приближении мелкой воды, активно развиваются в последние годы усилиями исследователей.

Статья посвящена к обзору математических исследований динамики процессов в неустановившихся течениях воды с помощью дифференциальных уравнений, а также оценке этих подходов с точки зрения отражения моделью реальных процессов.

Целью исследования является анализ различных подходов к моделированию динамики процессов в неустановившихся течениях воды. К задачам исследования относится анализ научных публикаций с различными подходами к моделированию уравнения мелкой воды учтенных факторов, параметров и методов моделирования.

Ключевые слова: Уравнения Сен-Венана, динамика неустановившихся течений реки, численные методы, система гиперболических дифференциальных уравнений, высокопроизводительные вычисления.

\title{
1 Introduction
}

Shallow water equations are widely used to model water flow in rivers or lakes. The equations of shallow water, the Saint-Venant equation was proposed in 1871 and the numerical solution of problems for these equations is an urgent problem in computational mathematics. The flows under the surface of the fluid are described by the Saint-Venant equations, which are a system of hyperbolic partial differential equations. This problem includes such important tasks as the problem of floods on rivers, the problem of daily and weekly regulation of productivity, and problems of the outflowing wave upon a dam break. For practical purposes, it is very important to have more accurate methods for solving this problem. Many problems 
require methods for calculating the flow of water taking into account various physical factors. For example, floods in the coastal zone by storm surge, flooding in rivers, the study of the interfluve problem. Application of the shallow water equation makes it possible to simplify the algorithm, as well as optimize the use of computational resources, which are considered to be a very important factor in solving applied problems and developing software systems.

\section{Material and methods}

\subsection{The formulation of the problem}

Two-dimensional Saint-Venant equations are used to control surface flow. These equations are derived from the continuity and momentum equations by depth averaging. The main assumptions used in the derivation of two-dimensional Saint-Venant equations are the distribution of hydrostatic pressure and a small channel slope. The defining equations for the surface flow are obtained as follows:

$$
\begin{aligned}
& \frac{\partial h}{\partial t}+\frac{\partial\left(h u_{x}\right)}{\partial x}+\frac{\partial\left(h u_{y}\right)}{\partial y}=0, \\
& \frac{\partial\left(h u_{x}\right)}{\partial t}+\frac{\partial\left(h u_{x}^{2}+\frac{g h^{2}}{2}\right)}{\partial x}+\frac{\partial\left(h u_{x} u_{y}\right)}{\partial y}=h f_{x}-g h \frac{\partial S}{\partial x}, \\
& \frac{\partial\left(h u_{x}\right)}{\partial t}+\frac{\partial\left(h u_{x} u_{y}\right)}{\partial x}+\frac{\partial\left(h u_{x}^{2}+\frac{g h^{2}}{2}\right)}{\partial y}=h f_{y}-g h \frac{\partial S}{\partial y} .
\end{aligned}
$$

Here $h(x, y, t)$ is the height of the liquid level above the bottom profile $S(x, y), u_{x}$ and $u_{y}$ are velocity components, $\mathrm{g}$ is gravity, $f_{x}$ and $f_{y}$ are external force components. For flows over a flat surface in the absence of external forces, the system of equations (1) - (3) is called the Saint-Venant equations.

There are a huge number of different methods for solving the shallow Saint-Venant equation. Among them, one can single out such methods as the method of difference schemes, the finite element method, the finite volume method, and others. Until now, the development of new approximation methods for solving such problems continues. This is due to the relevance of the tasks being considered. The main difficulty here consists in obtaining a stable difference solution to the problem. Such problems require special quality requirements for the numerical methods used.

In this paper, we give a brief overview of modern research on the properties of unsteady flows in open flows described by the system of Saint-Venant equations.

\section{Literature review}

In [1], an implicit difference grid scheme was developed for solving one-dimensional equations of unsteady motion in open rivers, which allows calculations with a large time step. This was especially important for the calculation of floods in large rivers when the duration of the computation process took a long time. The compiled program was widely used at the 
State Hydrological Institute of the USSR for numerical experiments and calculations of real objects. However, there is no description of the algorithm and no substantiation of the finite difference method itself.

In [2], a new and simpler mathematical statement of the problem of the wave motion along a dry channel was proposed. In this work, it is assumed that the Saint-Venant equations are valid for the entire flow region, and the boundary conditions at the wavefront are obtained by equating the front propagation speed and the flow velocity near the wave head. A difference scheme is also proposed, which allows to make calculations of unsteady motion in complex channel systems.

In [3], a method was developed for calculating the motion of discontinuous waves in nonprismatic channels with allowance for friction. The numerical method of calculation was based on the representation of Saint-Venant's equations in the so-called form of conservation laws and the use of a difference scheme with recalculation (on the motion of a discontinuous wave without isolating a discontinuity). To calculate the propagation of the discontinuous wave with the separation of the discontinuity, a movable grid was used, which is constructed in the course of the calculation. The application of this method showed satisfactory agreement with the experimental results.

Since 1970, grid methods have begun to appear for numerically solving Saint-Venant's equations. The disadvantage of the method was that the calculation required a large amount of computer time, although the computers of that time worked much slower than modern computers.

The work [4] is devoted to the problem of exponential stability of the solution of nonlinear Saint-Venant equations in differential form. The paper considers the general case when the system includes both arbitrary friction and a slope that changes in space, which leads to non-uniform steady states. An explicit quadratic Lyapunov function is constructed and local exponential stability is proved.

The monograph [5] is devoted to studying mixed problems for one-dimensional hyperbolic systems in canonical form. Lyapunov stability has been established in various functional spaces, in particular, numerous practical models have been considered. The issues of numerical solutions of mixed problems are not considered.

In [6], a discrete Lyapunov function was constructed for the telegraph equation, and its decrease was proved. The use of this approach for the San Venant equation is associated with difficulties that require additional research.

For hyperbolic equations with dissipative boundary conditions the exponential stability of the solution is established by the Lyapunov function method in [7].

In [8], algebraic conditions for the exponential stability of the solution of mixed problems of the linear Saint-Venant equations were obtained. The issue of the numerical solution is not considered.

For one-dimensional quasilinear hyperbolic systems, the problems with dissipative boundary conditions that guarantee the exponential stability of classical solutions are considered in [9]. There is no research on numerical calculations.

In [10], using the Volterra transform of the second kind and the invertible Fredholm transform, optimal control problems for general linear hyperbolic Qsystems are investigated.

We note that the papers [4], [5], [7]- [10] study questions related to the theoretical aspects of the solvability and stability of mixed problems for hyperbolic systems and do not consider 
A brief overview of modern research ...

the issues of constructing numerical solutions and the stability of difference schemes. In the numerical calculation of mixed problems for hyperbolic systems, the reason for the above is that the dimension of the system of linear algebraic equations increases with the size of the considered region. This leads to an unreasonably large volume of computations and requires the involvement of high-performance computing technology.

In [11], the authors propose a class of difference schemes for hyperbolic systems of equations that have several notation forms. The stability of the proposed difference schemes is investigated using the energy integrals technique. However, their application for the study of exponential stability is a rather difficult task.

The work [12] is devoted to the study of initial-boundary value problems for a class of quasilinear hyperbolic systems. An a priori estimate is obtained for the solution of the problem by the method of the integral of energy. The issues of the numerical solution and its stability are not studied.

In [13], a linear initial-boundary value problem of the dynamics of fluid-saturated porous media, described by three elastic parameters in a reversible hydrodynamic approximation, was numerically solved. The adequacy of the computational model remains open.

The book [14] is devoted to methods for solving high-order algebraic systems arising from the application of the grid method to problems of mathematical physics. Along with the iterative methods, which are most widely used in computational practice for solving these problems, direct methods are also presented.

Much progress has been made in the study of general properties and patterns of modeling shallow water in systems with open channels and reservoirs. However, the study of specific hydrological objects is important. Modelling river systems and reservoirs seem to be the most difficult. As positive examples of constructing multidimensional models for this kind of object, let us point out the lower course of the river Bureya beyond the Bureyskaya hydroelectric power station [15], as well as others.

Formally, Saint-Venant's equations are valid for the case when the height of the liquid level is much less than the characteristic dimensions of the problem, and the bottom shape is a sufficiently smooth function. The problem with a discontinuous bottom profile is being intensively studied in the framework of the Saint-Venant approximation. The construction of analytical solutions for such problems is rather laborious even for plane one-dimensional flows, and there is extensive literature on these issues [16]- [17]. In [18], the author constructed analytical solutions of the Saint-Venant equations for five characteristic problems of the decay of a discontinuity over a step and bottom step. Analytical solutions are used both to assess situations that arise in several practical cases and to test numerical algorithms aimed at calculating such flows. Such currents include, in particular, currents on the thresholds of sluices, currents when sluice gates are destroyed or when overflowing through the crest of a dam, currents in narrow sea straits with a complex bottom shape, and some other problems.

Difficulties in the numerical simulation of such flows are caused by the appearance of a complex configuration of discontinuities in the solution, caused both by the nonlinearity of the equations themselves and by the discontinuous profile of the underlying surface. In [19], methods are proposed to overcome these problems by isolating the discontinuity line associated with the position of the boundary of a step or step and modifying the system of Saint Venant equations. Using this approach makes the numerical algorithm more accurate, but deprives it of homogeneity. The latter is not always convenient when calculating practical 
problems. Another way to solve this problem is to use two-layer shallow water equations [20]. The construction of a homogeneous numerical algorithm for solving problems with bottom discontinuities also seems to be relevant.

In [21], based on the laws of conservation of momentum and mass of a liquid, a derivation of the hypothetical equations of Saint-Venant from the Navier-Stokes equations is given. When deriving the Saint-Venant equations, the authors used assumptions (the length of the watercourse is much greater than its depth and width, the channel is elongated in a straight line, the bottom slope is small, etc.).

In [22], a central-upwind difference scheme was proposed using the two-dimensional central approach developed in [23]. The simplest semi-discrete schemes in the center upstream were obtained in [24]- [26].

In the monograph [27], effective algorithms for the numerical solution of shallow water equations are presented, of which, first of all, it is necessary to single out the method of decay of an arbitrary discontinuity taking into account the discontinuous bottom, which ensures the existence and uniqueness of the solution for any initial data, as well as an algorithm for the equations of viscous shallow water and non-negative "algorithm for equations in the diffusion approximation. Thoroughly performed testing demonstrates the high accuracy and reliability of the proposed methods.

In [28], explicit schemes of the Lax-Wendroff and McCormack type of the second order of approximation were used for the numerical solution of the shallow water equations.

A numerical algorithm for solving problems of regulated shallow water equations on unstructured grids is described in [29]. In the above equations of shallow water, a small value of $\tau$ is introduced, which is called the regularization parameter or temporal smoothing and has the dimension of time. The terms with the coefficient $\tau$ are the regulating additives to the shallow water equations. The algorithm was tested and it was shown that the constructed solution is in good agreement with the calculation results by known numerical methods.

In [30], [31], a new numerical method for solving the shallow water equation was proposed and tested, based on the smoothing of the classical equations over some small time intervals. This procedure leads to the appearance of regulatory additives that ensure the stability of the numerical solution of the problem in a wide range of Froude numbers. This makes it possible to use the non-difference grid approximation and apply the flow form of equations without linearizing the original equations, which ensures strict observance of the laws of conservation of mass and momentum in the absence of external forces. This algorithm is universal for solving a wide class of problems; it allows us to calculate flows with moving areas of a dry bottom. Moreover, it is easy to parallelize and generalize to unstructured mesh design.

For the numerical solution of the shallow water equation, the regularization method, that is, the averaging of the equations over a certain short time interval was used in [32].

In [33], the long-range transport of impurities along the length of the Novosibirsk reservoir is investigated. The computational algorithm is constructed using a different scheme of increased accuracy for modeling the long-range transport of an impurity. It should be taken into account that a formal increase in the order of approximation of the advective terms of the equations leads to oscillating numerical solutions in the aeas of sharp changes in gradients. This led to the development of numerical algorithms adaptive to the solution, which ensure the preservation of the monotonicity of the numerical solution and a high order of numerical schemes. 
In [34], using the Lax-Wendroff scheme as an example, it is shown that the main reason for the reduction inaccuracy to the first order and below in TVD schemes in the calculation is that monotonicity in them is achieved by using various minimax procedures, which reduce the smoothness of the difference operators of flows. It is shown theoretically and numerically that the Lax-Wendroff scheme, in contrast to its TVD modifications, approximates the $\varepsilon$-Hugoniot conditions with the second-order at the fronts of non-stationary shock waves. At the same time, the Lax-Wendroff scheme reduces the order of convergence to the first one in the vicinity of the gradient catastrophe point, in which the discontinuous wave is formed. This decrease in convergence happens because this scheme, in contrast to compact schemes with artificial viscosities of a higher order of divergence, has only the first order of weak approximation on discontinuous solutions. In [35], 2D models of the Saint-Venant equation are considered and devoted to surface flows to study the behavior of flood waves. Open channel water runoff in drains and rivers is considered taking into account the fact that such streams are a source of flash floods. To predict and simulate flood behavior, a mathematical model is established with initial and boundary conditions using Saint-Venant 2D PDEs. The corresponding model is then discretized using an explicit finite difference method and implemented in MATLAB. For testing and implementation, a simple rectangular flow channel is considered.

\section{Results and discussion}

The first computer algorithms are associated with the processing of techniques and methods used in manual calculations. The method of explicit difference schemes and the method of characteristics require too much computation, especially when modeling river flows in channels with a complex form for calculations, which makes them ineffective. We should note that the shortcomings in the computations of riverbeds with complex shapes were associated with significant difficulties and led to an unjustifiably large amount of calculations.

The transition to the study of unsteady currents in rivers in the presence of discontinuities (discontinuous waves) naturally brings about new difficulties. Therefore, the first works in this direction were associated with several very serious simplifying assumptions.

Despite the successes achieved in this area, several problems remain unresolved here, and little attention is paid to some areas of research. Thus, in essence, there are no reliable methods for calculating the movement of the flood flow when the water leaves the floodplain.

Methods for calculating the propagation of discontinuous waves in channels with a complex outline, especially natural ones, need further improvement.

However, the simulation results are useful for understanding and predicting flood behavior at various locations in the flow channel at specific time intervals and can be useful in early warning systems for floods. It is also suggested that combining an underground flow with a surface flow may provide an even better approximation for flood circulation.

\section{Conclusion}

It can be said that the problem of unsteady movement in open channels has been and is being given great attention, as evidenced by several reports and scientific works. But, the theory of unsteady flows in eroded channels is being developed relatively poorly. The issues 
of exponential stability of numerical solutions to the shallow water equation, etc., have not been investigated.

In conclusion, we note that this review does not claim to be complete and deals mainly with the computational aspects of various problems for the Saint-Venant equation.

\section{Acknowledgement}

The work was supported by grant funding of scientific and technical programs and projects of the Ministry of Science and Education of the Republic of Kazakhstan (Grant No. AP08856594).

\section{References}

[1] Vasil'yev O.F., Godunov S.K., Pritvits N.A., Temnoyeva T.A., Fryazinova I.L., Shugrin S.M. Chislennyy metod rascheta rasprostraneniya dlinnykh voln $\mathrm{v}$ otkrytykh ruslakh i prilozheniye yego $\mathrm{k}$ zadache o pavodke[A numerical method for calculating the propagation of long waves in open channels and its application to flood problem] // Reports of the USSR Academy of Sciences. - 1963. - №151(3). - C. 525-527

[2] Shugrin S.M. O neodnorodnykh raznostnykh skhemakh[On inhomogeneous difference schemes] // Journal of Computational Mathematics and Mathematical Physics. - 1966. - T. 6, № 1. - C. 184-185. Q

[3] Vasil'yev O.F., Gladyshev M.T., Sudobicher V.G. Chislennoye resheniye zadach o teche niyakh s preryvnymi volnami $\mathrm{v}$ otkrytykh ruslakh[Numerical solution of problems on flows with discontinuous waves in open channels] // Numerical methods of continuum mechanics. - 1970. - T. 1. - № 5. - C. 3

[4] Hayat A., Shang P. A quadratic lyapunov function for saint-venant equations with arbitrary friction and space-varying slope // Automatica. - 2019. - V. 100. - P. 52-60.

[5] Bastin G., Coron J.M. Stability and Boundary Stabilization of 1-D Hyperbolic Systems. - Itemirkhauser Basel. - 2016. $307 \mathrm{p}$.

[6] GoEttlich S., Schillen P. Numerical discretization of boundary control problems for systems of balance laws: Feedback stabilization // European Journal of Control. - 2017. - V. 35. - P. 11-18.

[7] Bastin G., Coron J.M. A quadratic Lyapunov function for hyperbolic density-velocity systems with nonuniform steady states // Systems \& Control Letters. - 2017. - V. 104. - P. 66-71.

[8] Bastin G., Coron J.M., Novel, B.D. On Lyapunov stability of linearised Saint-Venant equations for a sloping channel // Networks and Heterogeneous Media. - 2009. - V. 4. - P. 177-187.

[9] Coron J.M., Bastin G. Dissipative boundary conditions for one-dimensional quasi-linear hyperbolic systems: Lyapunov stability for the $C^{1}$-norm // SIAM Journal on Control and Optimization. - 2015. - V. 53, № 3. - P. 1464-1483.

[10] Coron J.M., Hu Long, Olive G. Finite-time boundary stabilization of general linear hyperbolic balance laws via Fredholm backstepping transformation // Automatica Journal IFAC. - 2017. - V. 84. - P. 95-100.

[11] Blokhin A.M., Aloev R.D., Hudayberganov M.U. One Class of Stable Difference Schemes for Hyperbolic System // American Journal of Numerical Analysis. - 2014. - V. 6, № 3. - P. 85-89.

[12] Aloev R.D., Khudoyberganov M. U., Blokhin A.M. Construction and research of adequate computational models for quasilinear hyperbolic systems // Numerical Algebra, Control, and Optimization. - 2018. - V. 8, № 3. - P. 287-299.

[13] Berdyshev A.S., Imomnazarov Kh.Kh., Jian-Gang T., Mikhailov A. The Laguerre spectral method is applied to the numerical solution of a two-dimensional linear dynamic seismic problem for porous media // Open Computer Science. 2016. - V. 1. - P. 202-212.

[14] Samarskiy A.A., Nikolayev Ye.S. Metody resheniya setochnykh uravneniy [Methods for solving grid equations]. - Hayка. - 1978. - 532 c. 
[15] Klimovich V.I., Petrov O.A. Chislennoye modelirovaniye techeniy pri rabote vodoslivnoy plotiny Bureyskoy GES[Numerical modeling of currents during the operation of the spillway dam of the Bureyskaya HPP] // Izvestia of the All-Russian Scientific Research Institute of Hydraulic Engineering named after V.I. B.E. Vedeneeva. - 2012.- T. 266. - C. $22-37$.

[16] Alcrudoa F., Benkhaldoun F. Exact solutions to the Riemann problem of the shallow water equations with a bottom step // Computers \& Fluids. - 2001. - V. 30, № 6. - P. 643-671

[17] Han E., Warnecke G. Exact Riemann solutions to shallow water equations // Quarterly of Applied Mathematics. - 2014. - V. 72, № 3. - P. 1-44

[18] Bulatov O.V. Analiticheskiye i chislennyye resheniya uravneniy Sen-Venana dlya nekotorykh zadach o raspade razryva nad ustupom i stupen'koy dna[Analytical and numerical solutions of the Saint-Venant equations for some problems on the decay of a discontinuity over a step and bottom step] // Journal of Computational Mathematics and Mathematical Physics. - 2014. - T. 54, № 1. - C. 149-163

[19] Belikov V.V., Borisova N.M., Ostapenko V.V. Sovershenstvovaniye metodov chislennogo modelirovaniya gidrotekhnicheskikh sooruzheniy s rezkimi perepadami otmetok dna[Improvement of methods for numerical modeling of hydraulic structures with sharp drops in bottom elevations] // Safety of energy structures. - 2007. - T.16. -C. 79-89.

[20] Petrosyan A.S. Dopolnitel'nyye glavy gidrodinamiki tyazheloy zhidkosti so svobodnoy granitsey[Additional chapters of the hydrodynamics of a heavy fluid with a free boundary]. - Rotaprint IKI RAS. - 2010. - 65 c.

[21] Abduraimov M.G., Muzafarov KH.A., Puttiyev A.A. Dvizheniye vod v otkrytykh ruslakh (uravneniya SenVenana)[Abduraimov M.G., Muzafarov Kh.A., Puttiev A.A. Water movement in open channels (Saint-Venant equations)] // Math modeling. - 1998. - T. 10, № 6. -C. 97-106.

[22] Kurganov A. Finite-volume schemes for shallow-water equations // Acta Numerica. - 2008. - V. 27, № 6. -P. $289-351$.

[23] Jiang G.S., Tadmor E. Nonoscillatory central schemes for multidimensional hyperbolic conservation laws // SIAM J. Sci Comput. - 1998. - V. 19. -P. 1892-1917.

[24] Kurganov A., Levy D. Central-upwind schemes for the Saint-Venant system // M2AN Math. Model. Numer. Anal. - 2002. - V. 36. -P. 397-425.

[25] Kurganov A., Tadmor E. New high-resolution central schemes for nonlinear conservation laws and convection-diffusion equations // J. Comput. Phys. - 2000. - V. 160. -P. 241-282.

[26] Shirkhani H., Mohammadian A., Seidou O., Kurganov A. A well-balanced positivity-preserving central-upwind scheme for shallow water equations on unstructured quadrilateral grids // Comput. \& Fluids. - 2016. - V. 126. -P. 25-40.

[27] Belikov V.V., Aleksyuk A.I. Modeli melkoy vody v zadachakh rechnoy gidrodinamiki[Shallow water models in problems of river hydrodynamics]. - RAS. - 2020. - 345 c.

[28] Yan M., Cundy T.W. Modeling of Two-Dimensional Overland Flow // Water Resour.Res. - 1989. - V. 25, № 9. -P. 2019-2035.

[29] Yelizarova T.G., Bulatov O.V. Chislennyy algoritm resheniya regulyarizovannykh uravneniy melkoy vody na nestrukturirovannykh setkakh[Numerical algorithm for solving regularized shallow water equations on unstructured grids]. - Keldysh Institute of Applied Mathematics of the Russian Academy of Sciences. - 2014. - 25 c.

[30] Bulatov O.V., Yelizarova T.G. Regulyarizovannyye uravneniya melkoy vody i effektivnyy metod chislennogo modelirovaniya techeniy $\mathrm{v}$ neglubokikh vodoyemakh[Regularized shallow water equations and an effective method for numerical simulation of currents in shallow water bodies] // Journal of Computational Mathematics and Mathematical Physics. - 2011. - T. 51, № 1.- C. 7-184.

[31] Yelizarova T.G., Ivanov A.V. Chislennyy algoritm resheniya regulyarizovannykh uravneniy melkoy vody na nestrukturirovannykh setkakh[Numerical algorithm for solving regularized shallow water equations on unstructured grids]. - Keldysh Institute of Applied Mathematics of the Russian Academy of Sciences. - 2016. - 27 c.

[32] Kvon V.I., Kvon D.V., Zonov S.D., Karamyshev V.B. Chislennyy raschet techeniy i dal'nego perenosa primesi v ravninnykh rechnykh vodokhranilishchakh [Numerical calculation of currents and long-range transport of impurities in lowland river reservoirs] // Applied Mechanics and Technical Physics. - 2003. - T. 44, № 6.- C. 158-163.

[33] Zonov S.D., Kvon D.V., Kvon V.I. Chislennoye modelirovaniye protsessov perenosa primesi v pribrezhnoy zone vodokhranilishcha[Numerical modeling of pollutant transport processes in the coastal zone of the reservoir] // Environmental analysis of the region (theory, methods, practice). -2000. -C. 212-220. 
[34] Kamboh S.A., Izzatul N.S, Labadin J., Monday O.E. Simulation of 2D Saint-Venant equations in an open channel by using MATLAB // Journal of IT in Asia. - 2015. - V. 5, № 1. - P. 15-22.

[35] Blokhin A.M., Alayev R.D. Integraly energii i ikh prilozheniya k issledovaniyu ustoychivosti raznostnykh skhem[Energy integrals and their applications to the study of the stability of difference schemes]. - Novosibirsk University Publishing House. - 1993. - 224 c.

\section{Список литературы}

[1] Васильев О.Ф., Годунов С.К., Притвиц Н.А., Темноева Т.А., Фрязинова И.Л., Шугрин С.М. Численный метод расчета распространения длинных волн в открытых руслах и приложение его к задаче о паводке // Доклады АН CCCP. - 1963. - №151(3). - C. 525-527

[2] Шугрин С.M. О неоднородных разностных схемах // Журнал вычислительной математики и математической физики. - 1966. - Т. 6, № 1. - С. 184-185. Q

[3] Васильев О.Ф., Гладышев М.Т., Судобичер В.Г. Численное решение задач о тече ниях с прерывными волнами в открытых руслах // Численные методы механики сплошной среды. - 1970. - Т. 1. - № 5. - С. 3

[4] Hayat A., Shang P. A quadratic lyapunov function for saint-venant equations with arbitrary friction and space-varying slope // Automatica. - 2019. - V. 100. - P. 52-60.

[5] Bastin G., Coron J.M. Stability and Boundary Stabilization of 1-D Hyperbolic Systems. - Itemirkhauser Basel. - 2016. $307 \mathrm{p}$.

[6] GoEttlich S., Schillen P. Numerical discretization of boundary control problems for systems of balance laws: Feedback stabilization // European Journal of Control. - 2017. - V. 35. - P. 11-18.

[7] Bastin G., Coron J.M. A quadratic Lyapunov function for hyperbolic density-velocity systems with nonuniform steady states // Systems \& Control Letters. - 2017. - V. 104. - P. 66-71.

[8] Bastin G., Coron J.M., Novel, B.D. On Lyapunov stability of linearised Saint-Venant equations for a sloping channel // Networks and Heterogeneous Media. - 2009. - V. 4. - P. 177-187.

[9] Coron J.M., Bastin G. Dissipative boundary conditions for one-dimensional quasi-linear hyperbolic systems: Lyapunov stability for the $C^{1}$-norm // SIAM Journal on Control and Optimization. - 2015. - V. 53, № 3. - P. 1464-1483.

[10] Coron J.M., Hu Long, Olive G. Finite-time boundary stabilization of general linear hyperbolic balance laws via Fredholm backstepping transformation // Automatica Journal IFAC. - 2017. - V. 84. - P. 95-100.

[11] Blokhin A.M., Aloev R.D., Hudayberganov M.U. One Class of Stable Difference Schemes for Hyperbolic System // American Journal of Numerical Analysis. - 2014. - V. 6, № 3. - P. 85-89.

[12] Aloev R.D., Khudoyberganov M. U., Blokhin A.M. Construction and research of adequate computational models for quasilinear hyperbolic systems // Numerical Algebra, Control, and Optimization. - 2018. - V. 8, № 3. - P. 287-299.

[13] Berdyshev A.S., Imomnazarov Kh.Kh., Jian-Gang T., Mikhailov A. The Laguerre spectral method is applied to the numerical solution of a two-dimensional linear dynamic seismic problem for porous media // Open Computer Science. 2016. - V. 1. - P. 202-212.

[14] Самарский А.А., Николаев Е.С. Методы решения сеточных уравнений. - Наука. - 1978. - 532 с.

[15] Климович В.И., Петров О.А. Численное моделирование течений при работе водосливной плотины Бурейской ГЭС // Известия Всероссийского научно-исследовательского института гидротехники им. Б.Е. Веденеева. - 2012.- Т. 266. - C. $22-37$.

[16] Alcrudoa F., Benkhaldoun F. Exact solutions to the Riemann problem of the shallow water equations with a bottom step // Computers \& Fluids. - 2001. - V. 30, № 6. - P. 643-671

[17] Han E., Warnecke G. Exact Riemann solutions to shallow water equations // Quarterly of Applied Mathematics. - 2014. - V. 72, № 3. - P. 1-44

[18] Булатов О.В. Аналитические и численные решения уравнений Сен-Венана для некоторых задач о распаде разрыва над уступом и ступенькой дна // Журнал вычислительной математики и математической физики. - 2014. - Т. 54, № 1. - C. 149-163 
[19] Беликов В.В., Борисова Н.М., Остапенко В.В. Совершенствование методов численного моделирования гидротехнических сооружений с резкими перепадами отметок дна // Безопасность энергетических сооружений. - 2007. - Т.16. -C. $79-89$.

[20] Петросян А.С. Дополнительные главы гидродинамики тяжелой жидкости со свободной границей. - Ротапринт ИКИ PAH. - 2010. - 65 c.

[21] Абдураимов М.Г., Музафаров Х.А., Путтиев А.А. Движение вод в открытых руслах (уравнения Сен-Венана) // Математическое моделирование. - 1998. - Т. 10, № 6. -С. 97-106.

[22] Kurganov A. Finite-volume schemes for shallow-water equations // Acta Numerica. - 2008. - V. 27, № 6. -P. $289-351$.

[23] Jiang G.S., Tadmor E. Nonoscillatory central schemes for multidimensional hyperbolic conservation laws // SIAM J. Sci. Comput. - 1998. - V. 19. -P. 1892-1917.

[24] Kurganov A., Levy D. Central-upwind schemes for the Saint-Venant system // M2AN Math. Model. Numer. Anal. - 2002. - V. 36. -P. 397-425.

[25] Kurganov A., Tadmor E. New high-resolution central schemes for nonlinear conservation laws and convection-diffusion equations // J. Comput. Phys. - 2000. - V. 160. -P. 241-282.

[26] Shirkhani H., Mohammadian A., Seidou O., Kurganov A. A well-balanced positivity-preserving central-upwind scheme for shallow water equations on unstructured quadrilateral grids // Comput. \& Fluids. - 2016. - V. 126. -P. 25-40.

[27] Беликов В.В., Алексюк А.И. Модели мелкой воды в задачах речной гидродинамики. - РАН. - 2020. - 345 с.

[28] Yan M., Cundy T.W. Modeling of Two-Dimensional Overland Flow // Water Resour.Res. - 1989. - V. 25, № 9. -P. 2019-2035.

[29] Елизарова Т.Г., Булатов О.В. Численный алгоритм решения регуляризованных уравнений мелкой воды на неструктурированных сетках. - ИПМ им. М. В. Келдыша РАН. - 2014. - 25 с.

[30] Булатов О.В., Елизарова Т.Г. Регуляризованные уравнения мелкой воды и эффективный метод численного моделирования течений в неглубоких водоемах// Журнал вычислительной математики и математической физики. 2011. - Т. 51, № 1.- C. 7-184.

[31] Елизарова Т.Г., Иванов А.В. Численный алгоритм решения регуляризованных уравнений мелкой воды на неструктурированных сетках. - ИПМ им. М. В. Келдыша РАН. - 2016. - 27 с.

[32] Квон В.И., Квон Д.В., Зонов С.Д., Карамышев В.Б. Численный расчет течений и дальнего переноса примеси в равнинных речных водохранилищах // Прикладная механика и техническая физика. - 2003. - Т. 44, № 6.- С. $158-$ 163.

[33] Зонов С.Д., Квон Д.В., Квон В.И. Численное моделирование процессов переноса примеси в прибрежной зоне водохранилища // Экологический анализ региона (теория, методы, практика). -2000. -С. 212-220.

[34] Kamboh S.A., Izzatul N.S, Labadin J., Monday O.E. Simulation of 2D Saint-Venant equations in an open channel by using MATLAB // Journal of IT in Asia. - 2015. - V. 5, № 1. - P. 15-22.

[35] Блохин А.М., Алаев Р.Д. Интегралы энергии и их приложения к исследованию устойчивости разностных схем. Издательство Новосибирского университета. - 1993. - 224 с. 